\title{
Internship: A window of opportunity for improving diabetes
}

\section{care}

Sir,

Internship is a phase of training wherein a graduate is expected to conduct the actual practice of medical and health care and acquire skills under supervision so that he/she may become capable of functioning independently as doctor and as medical officers of government who run primary health centers. ${ }^{[1]}$

I was in final year when I read about diabetes mellitus to pass my examinations; at that time, I got interest in diabetes, so I tried for Indian Council of Medical Research short-term studentship, but unfortunately my topic was not selected. During my internship, I got an opportunity to continue my research. I used to sit in endocrine outpatient department where I came across many diabetic patients. It was very striking to see that there were so many patients of diabetes. Through a questionnaire, I screened and analyzed 150 patients of Type 2 diabetes regularly attending the diabetic clinic. I was fortunate to get an opportunity to see many patients of Type 1 diabetes, gestational diabetes mellitus, and a few cases of maturity-onset diabetes in young patients also.

In the cases I analyzed, many of them had been undetected for many years and diagnosis was made when they developed any complication such as retinopathies, diabetic foot, chronic kidney disease, skin infections, and many more. A few were incidentally detected during routine or executive health checkup through an abnormal blood or urine glucose test.

Most of the patients coming from lower socioeconomic group had poor control due to poor compliance with medication. Some patients were taking ayurvedic and Unani treatment, at times this was attributed to poor affordability.
I found that youngsters who have been recently diagnosed with diabetes sometimes do not wish to accept and reveal their condition due to the social stigma attached to the condition when seeking marital alliance.

Many patients were ignorant about their health; in spite of counseling, they did not follow the diet chart or take regular medicine.

During internship, I connected with the people, patients, and that made me feel, for the first time, what it meant to be a doctor. It helped me in narrowing the gap between theory and practice. Unfortunately, many students do not take internship period seriously.

\section{WHY DID I CHOOSE TO WORK IN DIABETES CARE?}

In India, diabetes and other noncommunicable diseases are relatively overshadowed by the persistent burden of communicable and nutrition-related diseases. Management of diabetes and its complications is a huge challenge owing to several problems, including a lack of general awareness about diabetes and its complications among the population, and scarcity of health-care personnel, monitoring equipment, and even drugs, especially in remote areas. Primary care doctors are what our nation needs most from its medical colleges. Exposure to diabetes patients as an intern can help to treat, create awareness, and counsel the patients. This is necessary to make them more responsive to meeting the community needs.

\section{HOW COULD WE IMIPROVE IT?}

1. One of the foremost aspects of diabetes care and management is timely diagnosis and adequate 
treatment. Patients of diabetes should be seen on priority basis without causing undue distress

2. Promoting adherence to treatment regimens (including diet, physical activity, and drugs) is a task that will have to be taken up by nonphysician health care workers, including nursing, paramedic staff, and health educators at all levels ${ }^{[2]}$

3. We could improve diabetes care by educating people about diabetes, its symptoms, its complications, what will influence drug compliance, and proper control

4. In rural areas, health facilities that are dependent on primary health centers and subcenters need upgradation because these are not well equipped due to inadequacy of facilities and skilled workforce ${ }^{[3]}$

5. The most successful practices have an institutional priority for quality of care improvements that means:

- Having a coordinated team of dedicated health-care professionals in an environment that prioritizes and encourages patient-centered, high-quality care

- Implementing electronic health record tools

- Removing financial barriers and reducing patient's out-of-pocket costs for diabetes education, eye examinations, self-monitoring of blood glucose, and necessary medications with a preference for low-cost generic medications. ${ }^{[4]}$

\section{CONCLUSION}

Internship is the period of maximum practical learning in MBBS training. I found internship as a window to improve my communication skills and clinical reasoning. It provided me more realistic experiences and vision as well as more patient contact that will be essential for my future professional practice. While doing research, my writing and reading skills have improved, and I now know how to cite any article and how to publish a research. Now I have something more than my other intern friends. I feel that every intern should take internship seriously; it does not need any extra hard work, just being attentive for few hours of internship make a lot of difference. This would be life changing for ourselves and for our patients.

\section{Acknowledgment}

I would like to thank Dr. Sushil Jindal (DM endocrinology) for his helpful guidance and support. I would also like to express my gratitude to Dr. Shaifali Bansal (MD medicine), who guided and helped me all along the way.

\section{Financial support and sponsorship}

Nil.

\section{Conflicts of interest}

There are no conflicts of interest.

Prakriti Samadhiya

People's College of Medical Sciences and Research Centre, Bhopal, Madhya Pradesh, India

Address for correspondence: Dr. Prakriti Samadhiya, People's College of Medical Sciences and Research Centre, Bhopal, Madhya Pradesh, India. E-mail: prakriti.samadhiya@gmail.com

\section{REFERENCES}

1. Medical Council of India. Salient Features of Regulations on Graduate Medical Education. New Delhi: MCl; 1997. Available from: http://www.mcindia.org/know/ rules/rules_mbbs.htm. [Last accessed on 2012 Jun 15].

2. Kalra S, Julka S, Joshi R, Shah A, Jindal S, Agrawal N, et al. Strengthening diabetes management at primary health level. Indian J Endocrinol Metab 2015;19:443 7.

3. Ali MK, Singh K, Kondal D, Devarajan R, Patel SA, Shivashankar R, et al. Effectiveness of a multicomponent quality improvement strategy to improve achievement of diabetes care goals: A Randomized, Controlled Trial. Ann Intern Med 2016;165:399 408.

4. Standards of medical care in diabetes-2017: Summary of revisions. Diabetes Care 2017;40 Suppl 1:S4-5.

This is an open access article distributed under the terms of the Creative Commons Attribution-NonCommercial-ShareAlike 3.0 License, which allows others to remix, tweak, and build upon the work non-commercially, as long as the author is credited and the new creations are licensed under the identical terms.

\begin{tabular}{|l|l|}
\hline \multicolumn{2}{|c|}{ Access this article online } \\
\hline Quick Response Code: & Website: \\
\hline & www.joshd.net \\
\cline { 2 - 2 } & Dol: \\
& 10.4103/joshd.J_Soc_Health_ \\
\hline
\end{tabular}

How to cite this article: Samadhiya P. Internship: A window of opportunity for improving diabetes care. J Soc Health Diabetes 2017;5:108-9.

(c) 2017 Journal of Social Health and Diabetes | Published by Wolters Kluwer - Medknow 